\title{
Alternative transcripts of the SERPINA1 gene in alpha-1 antitrypsin deficiency
}

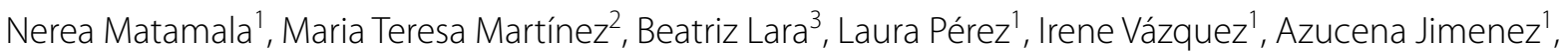
Miguel Barquín ${ }^{1}$, Ilaria Ferrarotti ${ }^{4}$, Ignacio Blanco ${ }^{5}$, Sabina Janciauskiene ${ }^{6,7}$ and Beatriz Martinez-Delgado ${ }^{*}$

\begin{abstract}
Background: SERPINA1 is the gene for alpha-1 antitrypsin (AAT), an acute phase protein with anti-protease and immunoregulatory activities. Mutations in SERPINA1 gene cause AAT deficiency and predispose individuals to earlyonset emphysema and liver diseases. Expression of the SERPINA1 gene is regulated by different promoters and alternative splicing events among non-coding exons $1 \mathrm{~A}, 1 \mathrm{~B}$ and $1 \mathrm{C}$.
\end{abstract}

Methods: We have developed three quantitative PCR (QT-PCR) assays (1A, 1B and 1C). These assays were applied for the analysis of SERPINA1 alternative transcripts in: (1) 16 human tissues and (2) peripheral blood leukocytes from 33 subjects with AAT mutations and 7 controls.

Results: Tissue-specific expression was found for the SERPINA1 transcripts. The 1A transcripts were mainly expressed in leukocytes and lung tissue while those detected with the 1B assay were highly restricted to leukocytes. Only 1B transcripts significantly correlated with serum AAT levels. The 1C transcripts were specifically found in lung, liver, kidney and pancreas. Furthermore, the expression of transcripts was related to AAT genotypes. While deficient variants of AAT had no pronounced effect on the transcript expression, null alleles were associated with significant reduction of different transcripts.

Conclusions: The possibility to discriminate between SERPINA1 alternative splicing products will help us to understand better the regulation of SERPINA1 gene and its association with SERPINA1 mutations-related diseases.

Keywords: Alpha-1 antitrypsin, Alpha-1 antitrypsin deficiency, SERPINA1, Transcription, Alternative splicing, Quantitative PCR

\section{Background}

Human alpha-1 antitrypsin (AAT), also named alpha-1 proteinase inhibitor $(\alpha 1-\mathrm{Pi})$ is the prototypic member of the serine protease inhibitor (SERPIN) superfamily of proteins [1]. AAT is codified by the SERPINA1 gene, which is located on human chromosome 14q32 [2-4], mapped in the same cluster together with other serpin genes, SERPINA3 ( $\alpha 1$-antichymotrypsin), SERPINA4 (kallistatin precursor), SERPINA5 (PCI, protein C inhibitor), SERPINA9 (centerin), SERPINA10 (ZPI, protein Z-dependent protease inhibitor) as well as SERPINA11

\footnotetext{
*Correspondence: bmartinezd@isciii.es

${ }^{1}$ Molecular Genetics Unit, Instituto de Investigación de

Enfermedades Raras (IIER), Instituto de Salud Carlos III (ISCIII), Carretera

Majadahonda-Pozuelo Km 2,200, 28220 Majadahonda, Madrid, Spain

Full list of author information is available at the end of the article
}

[5]. SERPINA genes have similarities in their structure and characteristically consist of four exons with identical positioning and phasing of the intron-exon boundaries. Interestingly, in spite of their close proximity, the corresponding proteins have different functions, raising important questions about the evolution of gene function and expression.

The structure of SERPINA1 is organized into three non-coding exons (1A, $1 \mathrm{~B}$ and $1 \mathrm{C})$, four coding exons (2-5) and six introns [2-4]. Expression of the SERPINA1 gene is controlled predominantly by two promoters in the $5^{\prime}$ untranslated region ( $\left.5^{\prime} \mathrm{UTR}\right)$ regulatory region. The hepatocyte SERPINA1 promoter is located upstream of the hepatocyte transcription start site, within exon $1 \mathrm{C}[4$, 6, 7]. An alternative promoter region, located upstream of exon 1A, controls SERPINA1 expression in other cells, 
such as monocytes and macrophages [7]. Therefore, the primary transcript generated in hepatocytes is smaller than two other major transcripts generated from exons $1 \mathrm{~A}$ and $1 \mathrm{~B}$. At least two different transcription start sites are located within the exon $1 \mathrm{~A}$, typically used in monocytes, whereas a third transcription site is located before exon 1B [8-10]. Additional transcription initiation sites for SERPINA1 gene expression were proposed for corneal cells and A549 lung cell line [11-13].

The transfer of the genomic information from DNA to RNA to protein is a highly complex process due to the generation of alternative gene products from a single gene locus [14]. This latter can occur through transcriptional or post-transcriptional (splicing) mechanisms [15]. Thus, almost all multi-exon human genes can generate multiple mRNA/transcript variants, which may encode isoforms having different biological functions [16, 17]. Studies on alternatively spliced isoforms suggested that changes in splicing are related to gene function and specific diseases $[18,19]$. Although splicing is an abundant phenomenon [20], characterization of splicing isoforms has not been performed for many genes, including SERPINA1 gene.

In the SERPINA1 gene, different transcripts are produced due to the use of different transcription initiation sites, and within non-coding exons $(1 \mathrm{~A}, 1 \mathrm{~B}$ and $1 \mathrm{C})$ the alternative splicing events occurring in a stimulus- and cell-type specific manner $[7,8,21]$. These facts highlight the importance of the $5^{\prime} \mathrm{UTR}$ region for the regulation of AAT expression.

AAT is expressed mainly by hepatocytes [9] although other cell types, including monocytes, macrophages, intestinal epithelial cells or cornea, also express this protein [12, 22-25]. The level of plasma AAT is controlled by a pair of co-dominant alleles and more than 100 variants have been described in the SERPINA1 gene [26]. For clinical purposes AAT variants are classified into four major categories: normal, deficiency, null and dysfunctional. The most common allele is $\mathrm{M}$ resulting in a normal concentration of functionally active protein. Reduced levels of the AAT protein are commonly associated with deficient $S$ and $Z$ alleles [27]. There are also other rare deficient variants of the gene and cases with null alleles where no protein is produced due to the nonsense, frameshift or splicing mutations leading to truncated proteins, unstable transcription or mRNA degradation. SERPINA1 gene produces several transcription products of putative clinical relevance. Therefore, it is of great interest to detect and quantify these products in different tissues, and to explore the effect of genetic variants of SERPINA1 on transcription levels of the gene. Quantitative real-time reverse transcription-PCR was used before to study SERPINA1 expression under different experimental conditions and to assess the effect of gene mutations on transcription [28, 29]. However, the quantification of the different SERPINA1 splicing isoforms has not been performed to date. Therefore, the development of methods to quantify the abundance of these isoforms, and the characterization of the splicing pattern in different tissues remains of great importance.

Quantitative real-time PCR (QT-PCR) is a "gold" standard for mRNA quantification and has occasionally been used for quantification of specific splicing isoforms [19, 30-33]. The aim of this study was to develop a QTPCR approach for measuring the expression level of the alternative transcripts of the SERPINA1 gene. Three different QT-PCR assays directed to non-coding exons $1 \mathrm{~A}, 1 \mathrm{~B}$ and $1 \mathrm{C}$ were designed allowing quantification of specific transcripts. In order to evaluate the clinical relevance of alternative splicing isoforms, the expression of these transcripts was assessed in a set of different human tissue samples and in the peripheral blood samples from AAT deficiency subjects with different genetic mutations.

\section{Methods \\ Material from human tissues}

Commercially available cDNA from human tissues (Human MTC Panel I and II, Clontech) were used to measure the expression of SERPINA1 transcripts in a total of 16 different human tissues including heart, brain, placenta, lung, liver, skeletal muscle, kidney, pancreas, colon, ovary, peripheral leukocytes, prostate, small intestine, spleen, thymus. Two or more different experiments were performed in triplicate for all tissues. Expression in tissues was normalized to the expression obtained in a peripheral leukocyte sample.

\section{AAT deficiency subjects samples}

Peripheral blood samples were obtained from 33 AATD subjects evaluated in the Spanish Registry of Patients with AAT Deficiency or in the Center for Diagnosis of Inherited Alpha-1 Antitrypsin Deficiency in Pavia, Italy, and seven healthy individuals with normal (MM) AAT genotype that were used as controls. All cases had previously been genotyped by sequencing of all coding exons to characterize the mutation present in each case. Signed informed consent for the study was obtained from all the subjects and the study was approved by the ethics committee of Instituto de Salud Carlos III. Cases with deficient genotypes were members of a total of 18 families carrying the common deficiency variants $(\mathrm{S}$ and $Z$ ), the rare deficiency variants MMalton and MProcida or the null alleles QOMattawa, QOPorto, QOMadrid, QOBrescia or MVarallo, in heterozygous or homozygous state (Table 1). Among carriers of mutations, 20 
Table 1 Genotype and AAT serum levels of the cases analyzed

\begin{tabular}{|c|c|c|c|c|}
\hline & ID & Genotype & $\begin{array}{l}\text { AAT serum } \\
\text { (mg/dl) }\end{array}$ & $\begin{array}{l}\text { Reason for } \\
\text { diagnosis }\end{array}$ \\
\hline 1 & 14520 & MM & 133 & Healthy control \\
\hline 2 & 120СТ02 & MM & 185 & Healthy control \\
\hline 3 & 120СТ03 & MM & 124 & Healthy control \\
\hline 4 & 120СT05 & MM & 120 & Healthy control \\
\hline 5 & 120СТ07 & MM & 132 & Healthy control \\
\hline 6 & 120СТ08 & MM & 170 & Healthy control \\
\hline 7 & GM1 & MM & 102 & Healthy control \\
\hline 8 & 12501 & $M Z$ & 70 & Lung disease \\
\hline 9 & 120СТ01 & ZZ & 18 & Lung disease \\
\hline 10 & 120СТ04 & $\mathrm{ZZ}$ & 23.6 & Lung disease \\
\hline 11 & 120CT06 & ZZ & 38 & Lung disease \\
\hline 12 & 120СТ09 & $\mathrm{ZZ}$ & 11.5 & Lung disease \\
\hline 13 & 14519 & $\mathrm{ZZ}$ & 20 & Lung disease \\
\hline 14 & $14 S 31$ & ZZ & 16.1 & Lung disease \\
\hline 15 & 13509 & M/MMalton & 63.2 & Lung disease \\
\hline 16 & $13 S 12$ & M/MMalton & 75.9 & Lung disease \\
\hline 17 & $13 S 13$ & M/MMalton & 84.7 & Family screening \\
\hline 18 & $14 S 27$ & M/MMalton & 70 & Family screening \\
\hline 19 & $14 S 28$ & M/MMalton & 74 & Family screening \\
\hline 20 & $14 S 30$ & M/MMalton & 76 & Family screening \\
\hline 21 & $14 S 29$ & MMalton/MMalton & 6 & Lung disease \\
\hline 22 & 13503 & S/MMalton & 67.2 & Lung disease \\
\hline 23 & $13 S 14$ & Z/MMalton & 45 & Lung disease \\
\hline 24 & $14 S 23$ & MProcida/MProcida & 17 & Lung disease \\
\hline 25 & $14 S 25$ & S/MProcida & 49 & Family screening \\
\hline 26 & $14 S 34$ & S/MProcida & 70 & Family screening \\
\hline 27 & $14 S 24$ & M/MProcida & 69 & Lung disease \\
\hline 28 & $14 S 35$ & M/MProcida & 83 & Family screening \\
\hline 29 & $14 S 36$ & M/MProcida & 81 & Family screening \\
\hline 30 & 14537 & M/MProcida & 70 & Family Screening \\
\hline 31 & 13505 & M/QOPorto & 72 & Family screening \\
\hline 32 & 13506 & M/QOPorto & 67 & Family screening \\
\hline 33 & $13 S 17$ & M/QOPorto & 65 & Family screening \\
\hline 34 & $13 S 07$ & QOPorto/QOMadrid & 8.7 & Family screening \\
\hline 35 & 13508 & QOPorto/QOMadrid & 9 & Lung disease \\
\hline 36 & $13 S 16$ & QOPorto/MProcida & 33.4 & Lung disease \\
\hline 37 & $13 S 02$ & M/QOMattawa & 73.7 & Lung disease \\
\hline 38 & $15 S 42$ & QOBrescia/QOBrescia & $<10$ & Lung disease \\
\hline 39 & $15 S 43$ & QOBrescia/QOBrescia & $<10$ & Lung disease \\
\hline 40 & $15 S 44$ & Z/Mvarallo & $<10$ & Lung disease \\
\hline
\end{tabular}

presented with lung disease and 13 were asymptomatic blood relatives identified by family screening.

AAT serum levels were previously determined by nephelometry. Genotypes and serum AAT levels are described in Table 1.

\section{RT-PCR to analyze alternatively spliced products}

Expression of different transcripts in tissues and peripheral blood white cells was evaluated by conventional reverse transcription polymerase chain reaction amplification (RT-PCR). Total RNA extraction was performed using RNAeasy kit (Qiagen, Hilden, Germany). Afterwards, cDNA synthesis was carried out by reverse transcription using the Maxima First Strand cDNA Synthesis kit (Thermo Scientific, Fermentas Life Sciences, St. Leon-Rot, Germany). Since alternative splicing can occur within non-coding exons $(1 \mathrm{~A}, 1 \mathrm{~B}$ and $1 \mathrm{C})$ generating different transcription products, in order to amplify the region between 1A-E2, 1B-E2 and 1C-E2, we used previously designed forward primers located in exons $1 \mathrm{~A}, 1 \mathrm{~B}$, and $1 \mathrm{C}$ as well as a reverse primer in exon 2 [28]. PCR was performed on $1 \mu \mathrm{l}$ of cDNA template and $100 \mathrm{ng}$ of each primer. The amplification conditions were as follows: 35 cycles of denaturation at $94^{\circ} \mathrm{C}$ for $45 \mathrm{~s}$, annealing at $60^{\circ} \mathrm{C}$ for $30 \mathrm{~s}$, and extension at $72^{\circ} \mathrm{C}$ for $30 \mathrm{~s}$. PCR products were separated by electrophoresis and visualized on gel-red stained $2 \%$ agarose gels.

\section{Quantitative PCR (QT-PCR) of SERPINA1 transcripts}

We quantitatively analyzed the expression of transcripts containing exon $1 \mathrm{~A}, 1 \mathrm{~B}$ or $1 \mathrm{C}$. Three different assays (1A, $1 \mathrm{~B}$ and $1 \mathrm{C}$ ) were defined (Figure 1; Additional file 1). For each assay specific primers were designed to amplify regions $1 \mathrm{~A}-\mathrm{E} 2,1 \mathrm{C}-\mathrm{E} 2$ and $1 \mathrm{~B}-1 \mathrm{C}$, and specific fluorescent labelled Taqman probes were selected (Universal probe library, UPL, Roche) (Figure 1a). To specifically amplify transcripts with the 1A-E2 junction, a boundary-spanning primer for the sequence encompassing the exon 1A to exon 2 junction (1Ae2_F:5'TGAGGAGA GCAGGAAAGGACA3') and a reverse primer in exon 2 (1Ae2_R:5'CTCAGCCAGGGAGACAGG3') together with the probe \#18, were used. Thus, with the $1 \mathrm{~A}$ assay we detected expression of transcript I (Figure 1b).

Assay $1 \mathrm{C}$ was designed to amplify a region between exon $1 \mathrm{C}$ and exon 2. Junction between exon $1 \mathrm{C}$ to $\mathrm{E} 2$ is present in different transcription products and therefore it was not possible to design primers able to distinguish between splicing isoforms containing this region (Figure 1b). For this assay primers $1 \mathrm{Ce} 2 \mathrm{~F}$ : $5^{\prime}$ TTAAATACGGACGAGG ACAGG $3^{\prime}$ and 1Ce2R: 5'ACGAGACAGAAGACGG CATT $^{\prime}$, and the probe \#73 were used. Another quantitative assay was designed to measure the expression of transcripts specifically containing exon $1 \mathrm{~B}$ and $1 \mathrm{C}$ junction, using a forward primer in 1B (1B1C_F:5'CAGCTAAGTG GTACTCTCCCAGA3') and a reverse primer in $1 C$ exon (1B1C_R:5'TCGTCCGTATTTAAGCAGTGG3') in combination with the probe \#39.

The cDNA samples from patients and normal cases were diluted and amplified using Taqman Fast advance 

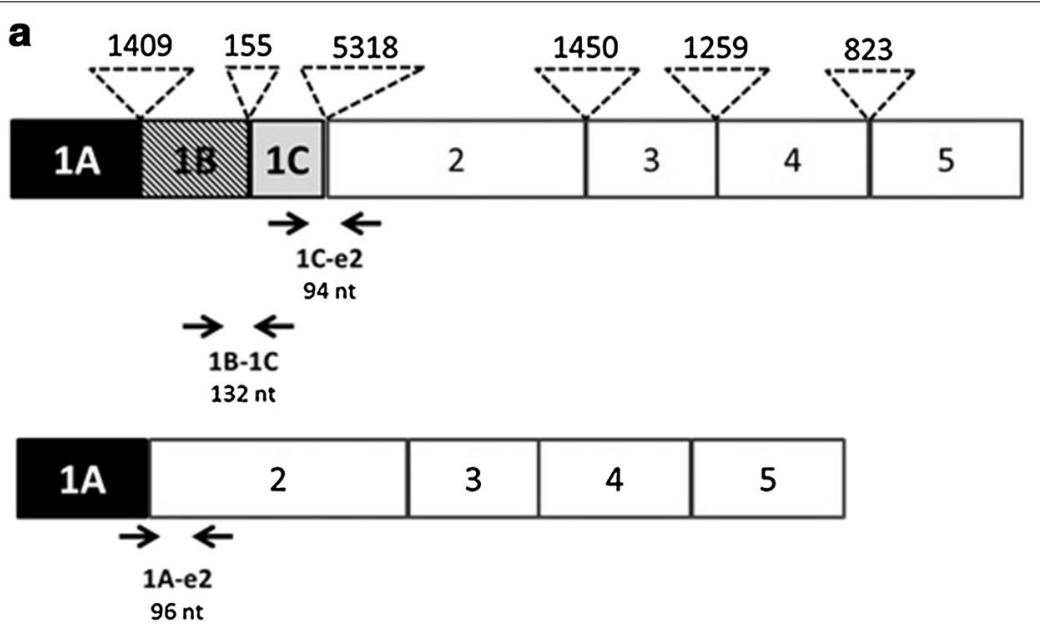

b

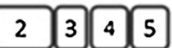

ENST00000355814 ENST00000440909

ENST00000437397

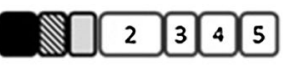

ENST00000448921

\section{ENST00000393087}
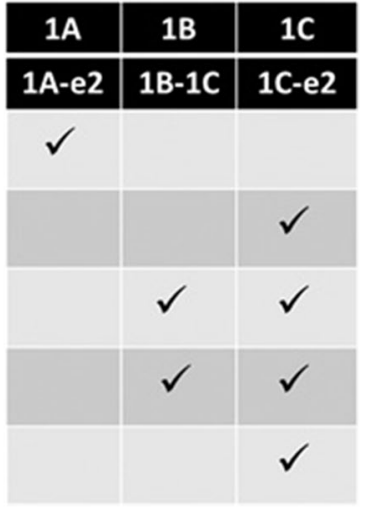

Figure 1 Representation of SERPINA1 gene and QT-PCR assays. a Schematic representation of the SERPINA1 gene exons with non-coding exons $(1 \mathrm{~A}, 1 \mathrm{~B}$ and $1 \mathrm{C})$ and exons $2-5$ coding for the AAT protein. Numbers above the non-coding and coding exons represent the intron length in bp. Locations of the different primers used for the three QT-PCR assays were represented by arrows. b Different alternative transcripts occur in the AAT gene by alternatively splicing of the non-coding exons 1A, 1B and 1C and the use of the different transcription start sites. Five transcripts (I, II, III, IV and $V$ ) can be detected with any of the assays $(1 \mathrm{~A}, 1 \mathrm{~B}$ and $1 \mathrm{C})$. The exon structure of these transcripts corresponds to isoforms found in Ensembl database listed in the Figure. Additionally, another transcript structure (IV), generated by transcription from exon 1B, is not represented in Ensembl database but transcription from exon 1B have been described in the literature [8-10].

master mix in a 7500 Fast Real Time PCR System (Applied Biosystems) with recommended PCR cycle conditions. Two genes (ACTB and GUSB) were used as endogenous controls to normalize the expression levels of SERPINA1 transcripts. All experiments were performed in triplicate and data were managed using the Applied Biosystems 7500 software v2.0. Relative expression was calculated by using the comparative $\mathrm{Ct}$ method and obtaining the fold-change value $(\Delta \Delta \mathrm{Ct})$. The $\Delta \mathrm{Ct}$ value of each sample was calculated using ACTB and GUSB, as an endogenous control genes. An inter-plate calibration sample was used to compare samples analyzed in different PCR plates.

\section{Statistical analysis}

Kolmogorov-Smirnov test was used to analyze the normal distribution of the data and bilateral $t$ test was applied using SPSS version 22 (SPSS Inc, Chicago, IL, USA). Nominal two-sided $\mathrm{p}$ values $<0.05$ were considered statistically significant. Correlation between expression levels of $1 \mathrm{~A}$, $1 \mathrm{~B}$ and $1 \mathrm{C}$ and serum levels of AAT were estimated by Pearson's coefficient. P values below 0.05 were considered as statistically significant.

\section{Results}

\section{QT-PCR assays for detection of alternative spliced} SERPINA1 isoforms

To quantify specific splicing transcripts of the SERPINA1 gene we developed a novel QT-PCR method (Figure 1). For this purpose exon-exon boundary spanning primer and primers located in alternative spliced exons $1 \mathrm{~B}$ and $1 \mathrm{C}$ were designed. Figure $1 \mathrm{~b}$ shows the different splicing transcripts that are detected using each of the QT-PCR assays (1A, $1 \mathrm{~B}$ and $1 \mathrm{C})$. 
Only transcript I contains the exon 1A directly joined to exon 2. Therefore, we employed a simple strategy using a primer spanning the exon $1 \mathrm{~A}$ to exon 2 junction, and as illustrated in Figure $1 \mathrm{~b}$, the $1 \mathrm{~A}$ assay specifically quantifies the expression of transcript I. On the other hand, the boundary between exon $1 \mathrm{C}$ and exon 2 is not specific and it is included in several transcript variants (II, III, IV and $\mathrm{V}$ ), which makes impossible individual quantification of transcripts containing this region. Therefore, the $1 \mathrm{C}$ assay amplifies and simultaneously detects several transcripts II, III, IV and V. Similarly, the 1B assay, which is developed to detect and quantify the boundary between exon $1 \mathrm{~B}$ and exon $1 \mathrm{C}$, allows only the combined quantification of transcripts III and IV (Figure 1b).

\section{Pattern of expression of SERPINA1 isoforms in human tissues}

The expression levels of different SERPINA1 transcripts were measured in a panel of various human tissues. Compared to other tissues, leukocytes showed a highest expression of the $1 \mathrm{~A}, 1 \mathrm{~B}$ and $1 \mathrm{C}$ transcripts (Figure 2). The transcript I, specifically detected with the $1 \mathrm{~A}$ assay, was mainly expressed in leukocytes and lung tissue but it was also detected in liver, colon, spleen, prostate, kidney or brain at much lower level (Figure 2). In addition to leukocytes, $1 \mathrm{C}$ transcripts were also expressed in lung, liver and kidney and less abundantly expressed in pancreas and small intestine (Figure 2). The expression of transcripts detected by using $1 \mathrm{~B}$ assay was almost exclusively restricted to leukocytes, although low expression was also found in lung and spleen. The commercial cDNA samples represent a pooled preparation from many individuals, therefore it is not possible to know which specific cell in the tissue samples is expressing the AAT transcripts. Further experiments using isolated cells remain to be performed.

\section{SERPINA1 expression in leukocytes from peripheral blood by RT-PCR}

White blood cells isolated from peripheral blood samples were used to analyze SERPINA1 expression. Since alternative splicing occurs between exons $1 \mathrm{~A}, 1 \mathrm{~B}$ and $1 \mathrm{C}$, we used forward primers located in these exons and antisense primers in exon 2 (Figure 3). We previously found a unique expression fragment [28] corresponding to a transcript, in which the exon $1 \mathrm{~A}$ is directly spliced to join exon 2 by skipping of the exons $1 \mathrm{~B}$ and $1 \mathrm{C}$ (Figure $3 \mathrm{~b}$ ). This transcript was initiated in any of the two transcription sites described within exon 1A [7]. However, with the primer located in exon $1 \mathrm{~B}$, several transcription products of different size were observed, reflecting the use of the different splicing sites located within exons $1 \mathrm{~B}$ and $1 \mathrm{C}$ (Figure $3 \mathrm{c}$ ). These products most likely begun in the initiation site described within exon 1B [7] since no alternative transcripts including exon $1 \mathrm{~B}$ or $1 \mathrm{C}$ were detected using the primer in exon 1A. Finally, as expected, amplification using primer in exon $1 \mathrm{C}$ generated only one fragment corresponding to joined exon $1 \mathrm{C}$ to exon 2 (Figure $3 \mathrm{~d}$ ). This region is present in all transcripts containing the exon 1C. Hence, we cannot determine whether its expression derived from the transcription site within exon $1 \mathrm{C}$ or within exons $1 \mathrm{~A}$ and $1 \mathrm{~B}$. Since our analysis was performed on white blood cells, this region most likely corresponds to transcripts starting

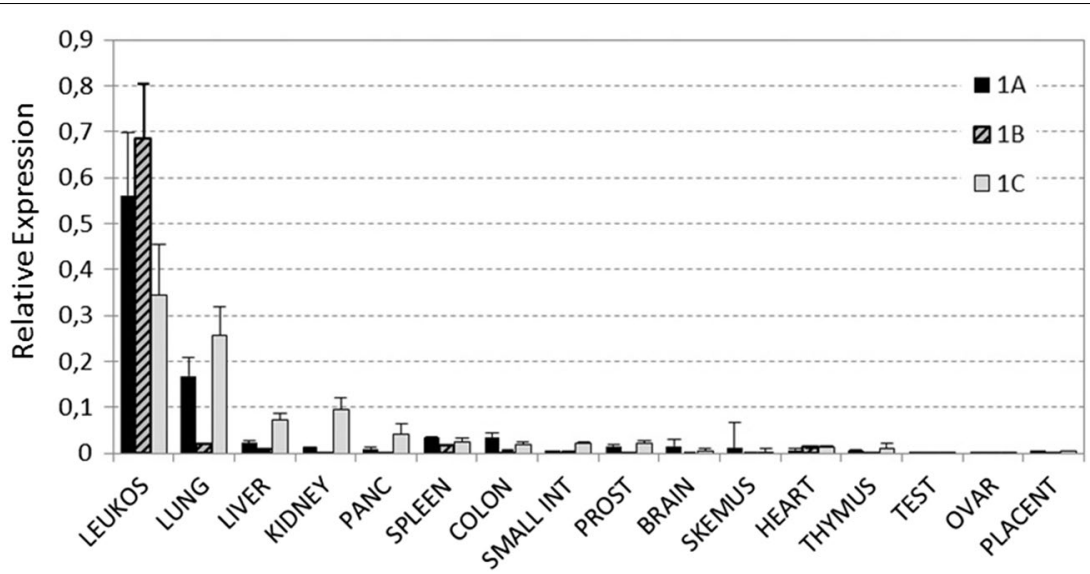

Figure 2 Transcription analyses of SERPINA1 transcripts in human tissues. Relative expression levels of $1 \mathrm{~A}, 1 \mathrm{~B}$ and $1 \mathrm{C}$ transcripts in 16 human tissues is shown. Specific patterns of transcript expression were detected in different tissues. Leukocytes exhibited higher expression levels of transcripts 1A, 1B, and 1C when compared to other tissues. The 1A transcript was found predominantly in leukocytes and lung tissue. Specific expression of $1 \mathrm{C}$ transcripts were detected in lung, liver, kidney or pancreas, suggesting that transcription in these tissues start in the transcription site located in exon 1C. Expression of 1B transcripts were almost exclusively detected in leukocytes. 

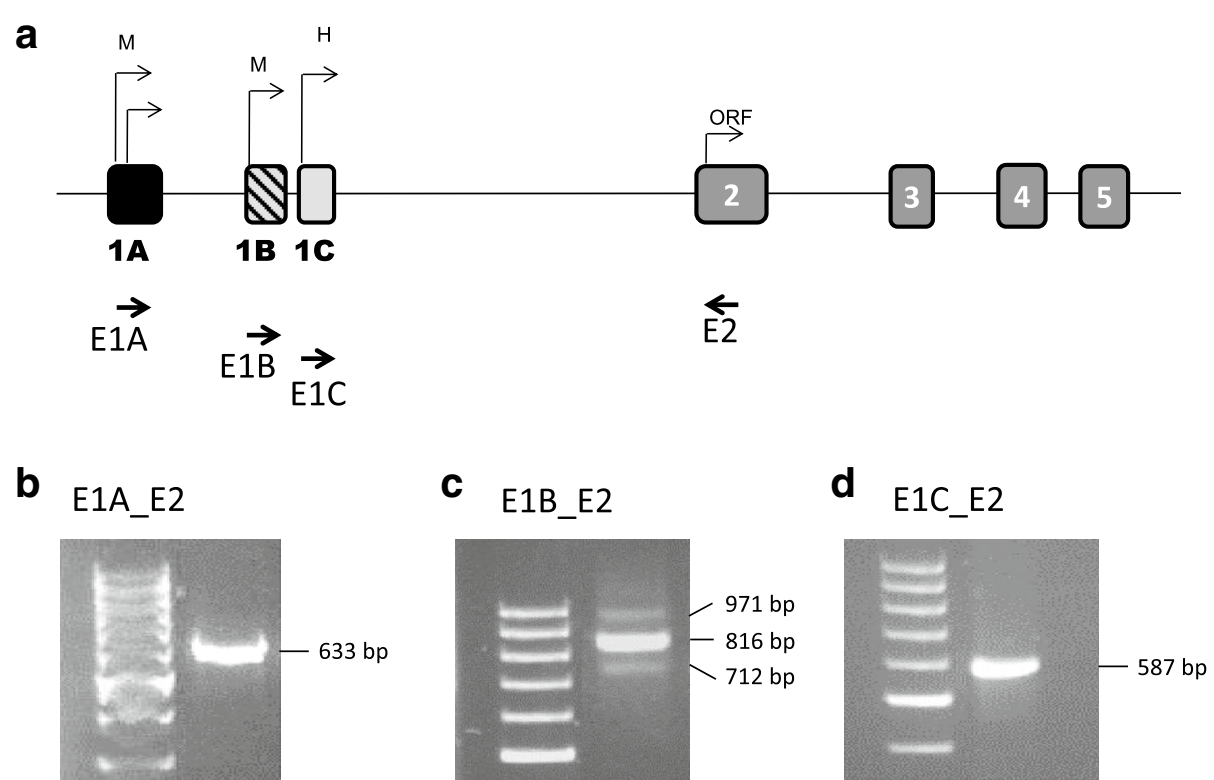

Figure 3 Representative expression of alternative transcripts in blood samples detected by RT-PCR. a Schematic graphic of the structure of the SERPINA1 gene. Primers used for RT-PCR expression analysis are represented by arrows. RT-PCR expression analysis in leukocytes from peripheral blood samples showed evidence for different alternative splicing event occurring within noncoding exons 1A, 1B and 1C of SERPINA1 gene. $\mathbf{b}$ Amplification fragment corresponding to the expression in blood samples detected using a forward primer in exon $1 \mathrm{~A}$ and a reverse primer in exon 2. A single band of $633 \mathrm{bp}$ was detected which corresponded to a transcript containing exon $1 \mathrm{~A}$ joined directly to exon 2. c Bands detected by using forward primer 1B. Different expression fragments were detected corresponding to splicing variants. The structure of these splicing variants has been described in detail before [28]. Three different bands are clearly visualized due to the different splicing sites used within exons 1B and 1C. The band of $712 \mathrm{bp}$ corresponded to the exon $1 \mathrm{~B}$ joined to exon 2. The band of $816 \mathrm{bp}$ corresponded to an isoform containing both exons $1 \mathrm{~B}$ and 1C. The upper band of 971 corresponds to a fragment with retained intron in between exons $1 \mathrm{~B}$ and $1 \mathrm{C}$. $\mathbf{d}$ Using a forward primer in the exon $1 \mathrm{C}$ a single band of $587 \mathrm{bp}$ was amplified.

at any of the monocyte transcription sites. Therefore, we think that leukocytes have active $1 \mathrm{~A}$ and $1 \mathrm{~B}$ transcription start sites.

\section{Effect of SERPINA1 mutations on alternative transcripts expression}

Three QT-PCR assays (1A, 1B and 1C, Figure 1) were applied on the peripheral blood samples from 33 AAT deficient subjects and 7 controls with normal MM genotype of AAT (Figure 4a). Subjects were carriers of heterozygous or homozygous variants of AAT (Z, S, MMalton, MProcida) or specific null alleles (QOMattawa, QOPorto, QOMadrid, QOBrescia or MVarallo) (Table 1). Notably, controls showed similar expression levels of transcripts detected either by $1 \mathrm{~A}, 1 \mathrm{~B}$ and $1 \mathrm{C}$ assays, although expression of the transcript I, detected by the $1 \mathrm{~A}$ assay, was slightly higher as compared to $1 \mathrm{~B}$ and $1 \mathrm{C}$ transcripts (Figure $4 \mathrm{~b}$ ). When compared to controls, ZZ patients showed no difference in the transcript levels. Interestingly, the level of $1 \mathrm{~A}$ transcript appeared higher in cases carrying either one or two deficient AAT alleles (Figure 4b), and even higher in null cases caused by the splicing mutations but not by stop gain mutations
(Figure 4a). Nevertheless, most cases with deficient alleles, such as heterozygous MMalton or MProcida alone or in combination with $\mathrm{S}$ or $\mathrm{Z}$ alleles, showed no significant changes in expression of the $1 \mathrm{~B}$ and $1 \mathrm{C}$ transcripts (Figure 4b). This supports the notion that $\mathrm{Z}$ and other deficiency mutations do not affect the transcription of AAT. However, when compared to MM controls, null cases showed reduced levels of transcripts. Transcripts $1 \mathrm{~B}$ and $1 \mathrm{C}$ were significantly reduced in carriers of either one or two null alleles with splicing mutations (QOPorto and QOMadrid) affecting the splicing donor site of intron $1 \mathrm{C}$. In two cases carrying these two splicing mutations affecting both alleles, $1 \mathrm{C}$ transcripts were almost completely absent (Figure 4a). Null alleles caused by stop-gain mutations (QOMattawa and QOBrescia) showed substantial decrease in all transcripts. However, the null allele Mvarallo in combination with $\mathrm{Z}$ did not display any change in transcript levels.

\section{Correlation between expression of different transcripts and they association with AAT protein levels}

The expression of transcripts detected with $1 \mathrm{~B}$ and $1 \mathrm{C}$ assays showed a significant correlation $(\mathrm{r}=0.83$, 


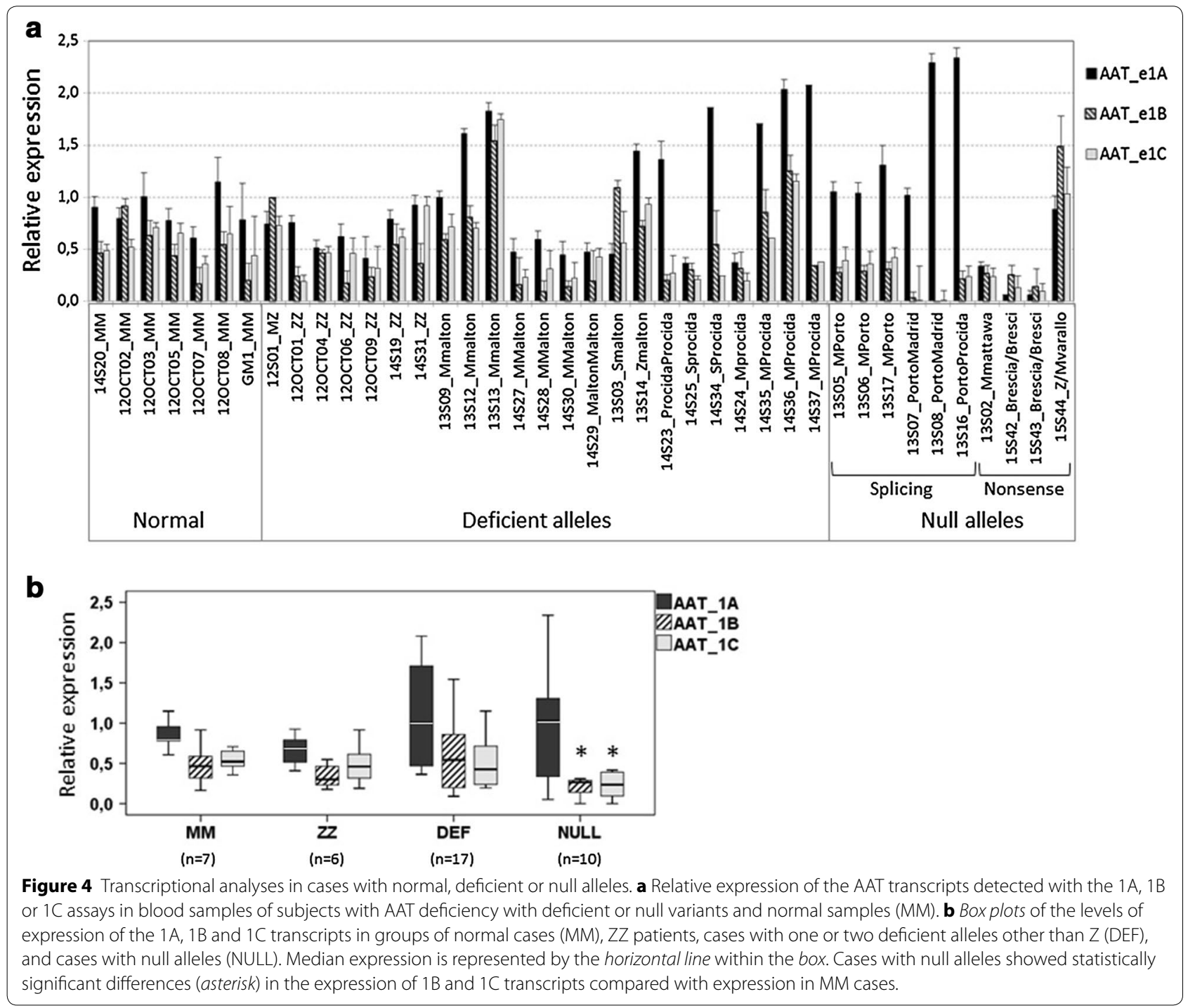

$\mathrm{p}<0.0001)$ in all analyzed cases. This finding suggests that (1) both assays are detecting the same transcription products and (2) the expression detected with the $1 \mathrm{C}$ assay comes from the monocyte transcription initiation sites but not from the hepatocyte specific transcript initiating in $1 \mathrm{C}$ exon. In contrast, the expression of $1 \mathrm{~B}$ and $1 \mathrm{C}$ transcripts did not correlate with the different human tissues analyzed, indicating that the $1 \mathrm{C}$ expression, at least in lung, liver, kidney or pancreas tissues (Figure 2) comes from the hepatocyte transcription start site. The expression of $1 \mathrm{~A}$ transcript did not correlate with $1 \mathrm{~B}(\mathrm{r}=0.27$, $\mathrm{p}=0.104)$ or $1 \mathrm{C}(\mathrm{r}=0.25, \mathrm{p}=0.138)$ expression. Notably, in peripheral blood cells the $1 \mathrm{~A}$ transcript was expressed at a higher level than $1 \mathrm{~B}$ and $1 \mathrm{C}$ transcripts.

In all subjects we found no significant correlation between serum levels of AAT protein and mRNA of AAT by using $1 \mathrm{~A}$ or $1 \mathrm{C}$ assays. In the other hand, AAT mRNA detected by the $1 \mathrm{~B}$ assay showed a weak correlation with serum levels of AAT protein $(\mathrm{r}=0.34, \mathrm{p}=0.04)$ (Figure 5). When $1 \mathrm{~B}$ assay was applied for cases with deficient AAT alleles, levels of mRNA well correlated with serum AAT levels $(r=0.50, p=0.016)$. Notably, this correlation did not exist in null cases.

\section{Discussion}

Splicing variants have not yet been characterized for many genes and the contribution of most splicing events to human diseases, including AAT deficiency, remains unclear. The involvement of alternative splicing events in diagnosis and disease prognosis becoming increasingly recognized [17, 18]. This demands development of new methods to quantify the abundance of these isoforms 


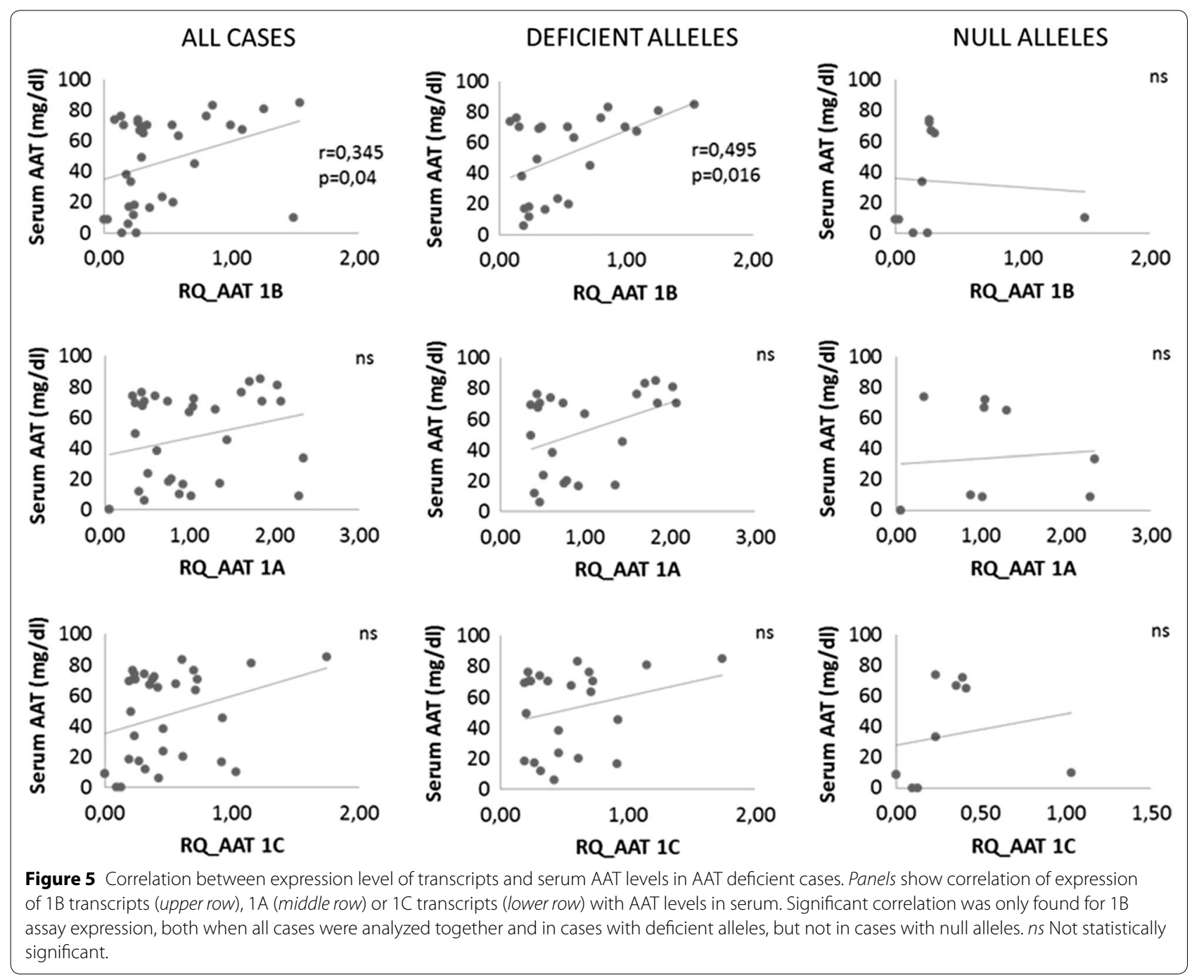

in clinical samples. The QT-PCR is a "gold" standard method to analyze splicing variants; however it is limited by the difficulties in designing primers specific to splicing isoforms [30, 34, 35].

We have developed a new QT-PCR method, which allows analysis of the expression of different SERPINA1 transcripts generated by the alternative splicing between non coding exons $1 \mathrm{~A}, 1 \mathrm{~B}$ and $1 \mathrm{C}$ of the gene. Three QTPCR assays were designed by using primers spanning the exon-exon junction (assay 1A) or primers flanking the alternatively spliced regions (assays $1 \mathrm{~B}$ and $1 \mathrm{C}$ ). Since some of the AAT noncoding exons are part of different transcript isoforms, separate quantification was only possible for transcripts with exon $1 \mathrm{~A}$ joined to exon 2 (transcript I, Figure 1b). Nevertheless, we were able to estimate the abundance of transcripts containing different combinations of exons $1 \mathrm{~B}$ or $1 \mathrm{C}$.
The regulation of the expression of the SERPINA1 gene is complicated because of the existence of two different promoter regions with several transcription start sites and the phenomenon of alternative splicing, leading to the potential production of different SERPINA1 transcription products. At present 19 splice variants of the SERPINA1 are described in the Emsembl Genome Browser. Despite this large number of transcripts, only five of them represent main isoforms containing all coding exons and $3^{\prime} \mathrm{UTR}$ sequence with different combinations of non-coding $1 \mathrm{~A}, 1 \mathrm{~B}$ and $1 \mathrm{C}$ exons.

So far, the expression of SERPINA1 gene has been analyzed without taking into account different transcription products of the gene. Therefore, the role of the different mRNA SERPINA1 products in different cell types and tissues remains to be established. The analysis of different transcription products using our developed QT-PCR 
assays, permitted elucidation of the specific pattern of SERPINA1 transcripts in different tissues. The QT-PCR results revealed that transcripts containing exons $1 \mathrm{~B}$ and $1 \mathrm{C}$ (transcripts III and IV, Figure 1b) are highly restricted to leukocytes. However, transcript containing exon $1 \mathrm{~A}$ bond to exon 2 (transcript I), although expressed at high level in leukocytes, was also detected in lung tissue and less abundantly in liver, spleen, colon and prostate. Hence, the monocyte transcription start sites located within exon 1A seems to be active in other tissues. Nevertheless, currently we cannot dismiss the possibility that this expression comes from monocytes/macrophages present in the specific tissue.

Expression of different transcripts in lung, liver, kidney, pancreas, spleen, colon, small intestine and prostate detected by the $1 \mathrm{C}$ assay was higher than detected by $1 \mathrm{~A}$ and $1 \mathrm{~B}$ assays. We believe that the $1 \mathrm{C}$ expression in these tissues reflects the expression of transcript $\mathrm{V}$ initiated in the hepatocyte transcription start site. Indeed, transcripts from $1 \mathrm{C}$ might be specifically expressed in extra-hepatic tissues. In fact, this was previously reported in transgenic mice studies [36-38]. Further studies in isolated cell types are warranted to elucidate the biological role of these different transcripts.

Furthermore, we found changes in the expression of specific transcripts in blood samples from subjects with AAT deficiency variants. As a matter of fact, null alleles produced by premature stop codons showed reduced levels of all transcripts. This latter could be explained by the activation of the nonsense mediated decay (NMD) mechanism typically occurring in null cases $[39,40]$. This was specifically found in homozygous QOBrescia/QOBrescia cases and even in the M/QOMattawa. In null alleles caused by splicing mutations (QOPorto and QOMadrid) the reduction in $1 \mathrm{~B}$ and $1 \mathrm{C}$ transcript levels might be explained by the fact that these splicing variants are localized in the donor splice site of exon 1C. It is probable that other null alleles, typically produced by premature stop codons, may have reduced levels of transcription. Supporting this assumption some researchers have found important effects of different AAT null mutations on the AAT mRNA level, such as QOGranite falls or QOTrastevere [41]. In general, cellular content of AAT mRNA is assumed to be affected by the distance of the nonsense codon from the initiator codon, although elements within the coding region may also have importance in conferring mRNA stability. Because transcription depends on the mutation, it is important to investigate whether other AAT variants (deficient and null) affect 1A, 1B or 1C transcription levels. Our QT-PCR approach might help to identify how mutations affect transcription of the AAT gene.

Remarkably, subjects with deficient AAT alleles like Z, S, MMalton, and MProcida showed no significant differences in $1 \mathrm{~A}, 1 \mathrm{~B}$ or $1 \mathrm{C}$ transcription levels relative to normal MM cases. Pathogenesis of the deficient variants of AAT is typically characterized by intracellular accumulation of AAT and a concomitant reduction in its circulating levels but not by the reduction in protein synthesis. Therefore, one cannot expect significant changes to occur at the mRNA level of the transcripts.

As AAT is an acute phase reactant, its expression increases during inflammatory responses. Although AAT is primarily synthesized in the liver [4], other cells also can produce lower amounts of AAT. Basal and modulated expression of AAT is controlled by many different cis and trans-acting factors that can substantially activate transcription $[7,11,42,43]$. The increased secretion of AAT is mainly mediated by the cytokines, such as IL-6, IL- $1 \beta$, $\mathrm{TNF} \alpha$, oncostatin M or bacterial lipopolysaccharide [21, $42,43]$. These stimuli seem to act specifically on hepatocytes, monocytes, macrophages or other AAT producing cells, and to induce expression of AAT by the different magnitude [29]. How all these factors affect expression, stability or translation rates of the different SERPINA1 transcripts remains to be elucidated.

\section{Conclusion}

We developed three QT-PCR assays to quantify the expression of SERPINA1 transcripts. By using these assays we quantified specific expression of transcripts in various tissues and found that transcript expression is affected by the deficient and null variants of SERPINA1 gene. The possibility to distinguish specific alternative transcripts opens new possibilities to explore the clinical importance of SERPINA1 gene mutations. Moreover, it helps to build a better understanding of regulation mechanisms of SERPINA1 gene expression. To understand the function of individual transcript variants in isolated cells from individuals with AAT deficiency will be the next step of our investigations.

\section{Additional file}

Additional file 1. Estructure of the main transcripts of SERPINA1 gene and their corresponding transcripts in Ensemble.

\section{Abbreviations}

AAT: alpha-1 antitrypsin; QT-PCR: quantitative polymerase chain reaction; RTPCR: reverse transcription polymerase chain reaction amplification; 5'UTR: $5^{\prime}$ untranslated region; NMD: nonsense mediated decay.

\section{Authors' contributions}

NM, performed experiments, analyzed transcriptional data, and helped to write the manuscript. MTM, carried out clinical assessment of patients, collected and provided samples and interpretation of the results. BL, participated in the design of the study, helped to collect clinical data, analyzed results, and drafted the manuscript. LP, IV, AJ, MB, performed the experiments, and analyzed transcriptional data. IF, provided samples, participated in the interpretation of the results and critically reviewed the results. SJ, participated in 
analyses and interpretation of results, helped to draft and critically reviewed the manuscript. IB, participated in interpretation of the results, involved in drafting the manuscript and reviewed it critically. BMD participated in the design and coordination of the study, analyzed data and drafted the manuscript. All authors read and approved the final manuscript.

\section{Author details}

${ }^{1}$ Molecular Genetics Unit, Instituto de Investigación de Enfermedades Raras (IIER), Instituto de Salud Carlos III (ISCIII), Carretera Majadahonda-Pozuelo Km 2,200, 28220 Majadahonda, Madrid, Spain. ${ }^{2}$ Pneumology Department, Hospital 12 de Octubre, Madrid, Spain. ${ }^{3}$ Respiratory Medicine Department, Royal Exeter and Devon Hospital, Exeter, Devon, UK. ${ }^{4}$ Section of Pneumology, Department of Molecular Medicine, Center for Diagnosis of Inherited Alpha-1 Antitrypsin Deficiency, IRCCS San Matteo Hospital Foundation, University of Pavia, Pavia, Italy. ${ }^{5}$ Alpha1-Antitrypsin Deficiency Spanish Registry, Lung Foundation RESPIRA, Spanish Society of Pneumology (SEPAR), Barcelona, Spain. ${ }^{6}$ Department of Respiratory Medicine, Hannover Medical School, Hanover, Germany. ${ }^{7}$ Biomedical Research in Endstage and Obstructive Lung Disease Hannover (BREATH), Member of the German Center for Lung Research (DZL), 30626 Hanover, Germany.

\section{Acknowledgements}

We thank collaborators from the REDAAT (Spanish Registry of Alpha-1 Antitrypsin deficiency patients) and all members of the Human Genetics Area of the ISCIII for their support. Special thanks to Prof. Halpin for reviewing the manuscript. This work has been partially funded by the Instituto de Salud Carlos III Grants TPY1250/12, TPY1269/15 and PI14CIII/00070 (BMD).

\section{Compliance with ethical guidelines}

\section{Competing interests}

The authors declare that they have no competing interests.

Received: 16 March 2015 Accepted: 25 June 2015

Published online: 04 July 2015

\section{References}

1. Lomas DA, Mahadeva R (2002) Alpha1-antitrypsin polymerization and the serpinopathies: pathobiology and prospects for therapy. J Clin Invest 110:1585-1590

2. Brantly M, Nukiwa T, Crystal RG (1988) Molecular basis of alpha-1-antitrypsin deficiency. Am J Med 84:13-31

3. Crystal RG (1989) The alpha 1-antitrypsin gene and its deficiency states. Trends Genet 5:411-417

4. Long GL, Chandra T, Woo SL, Davie EW, Kurachi K (1984) Complete sequence of the cDNA for human alpha 1-antitrypsin and the gene for the $S$ variant. Biochemistry 23:4828-4837

5. Billingsley GD, Walter MA, Hammond GL, Cox DW (1993) Physical mapping of four serpin genes: alpha 1-antitrypsin, alpha 1-antichymotrypsin corticosteroid-binding globulin, and protein C inhibitor, within a 280-kb region on chromosome 14q32.1. Am J Hum Genet 52:343-353

6. Ciliberto G, Dente L, Cortese R (1985) Cell-specific expression of a transfected human alpha 1-antitrypsin gene. Cell 41:531-540

7. Kalsheker N, Morley S, Morgan K (2002) Gene regulation of the serine proteinase inhibitors alpha1-antitrypsin and alpha1-antichymotrypsin. Biochem Soc Trans 30:93-98

8. Hafeez W, Ciliberto G, Perlmutter DH (1992) Constitutive and modulated expression of the human alpha 1 antitrypsin gene. Different transcriptional initiation sites used in three different cell types. J Clin Invest 89:1214-1222

9. Perlino E, Cortese R, Ciliberto G (1987) The human alpha 1-antitrypsin gene is transcribed from two different promoters in macrophages and hepatocytes. EMBO J 6:2767-2771

10. Rollini P, Fournier RE (2000) Differential regulation of gene activity and chromatin structure within the human serpin gene cluster at 14q32.1 in macrophage microcell hybrids. Nucleic Acids Res 28:1767-1777
11. Li Y, Zhou L, Twining SS, Sugar J, Yue BY (1998) Involvement of Sp1 elements in the promoter activity of the alpha1-proteinase inhibitor gene. Biol Chem 273:9959-9965

12. Boskovic G, Twining SS (1998) Local control of alpha1-proteinase inhibitor levels: regulation of alpha1-proteinase inhibitor in the human cornea by growth factors and cytokines. Biochim Biophys Acta 1403:37-46

13. Morgan K, Chappell S, Guetta-Baranes T, Morley S, Kalsheker N (2009) The alpha-1-antitrypsin gene promoter in human A549 lung derived cells, and a novel transcription initiation site. Int J Biochem Cell Biol 41:1157-1164

14. Moore MJ, Proudfoot NJ (2009) Pre-mRNA processing reaches back to transcription and ahead to translation. Cell 136:688-700

15. Hollstein M, Hainaut P (2010) Massively regulated genes: the example of TP53. J Pathol 220:164-173

16. Trapnell C, Williams BA, Pertea G, Mortazavi A, Kwan G, van Baren MJ et al (2010) Transcript assembly and quantification by RNA-Seq reveals unannotated transcripts and isoform switching during cell differentiation. Nat Biotechnol 28:511-515

17. Wang ET, Sandberg R, Luo S, Khrebtukova I, Zhang L, Mayr C et al (2008) Alternative isoform regulation in human tissue transcriptomes. Nature 456:470-476

18. Tazi J, Bakkour N, Stamm S (2009) Alternative splicing and disease. Biochim Biophys Acta 1792:14-26

19. Venables JP (2006) Unbalanced alternative splicing and its significance in cancer. BioEssays 28:378-386

20. Modrek B, Resch A, Grasso C, Lee C (2001) Genome-wide detection of alternative splicing in expressed sequences of human genes. Nucleic Acids Res 29:2850-2859

21. Knoell DL, Ralston DR, Coulter KR, Wewers MD (1998) Alpha 1-antitrypsin and protease complexation is induced by lipopolysaccharide, interleukin1 beta, and tumor necrosis factor-alpha in monocytes. Am J Respir Crit Care Med 157:246-255

22. de Serres F, Blanco I (2014) Role of alpha-1 antitrypsin in human health and disease. J Intern Med 276:311-335

23. du Bois RM, Bernaudin JF, Paakko P, Hubbard R, Takahashi H, Ferrans V et al (1991) Human neutrophils express the alpha 1-antitrypsin gene and produce alpha 1-antitrypsin. Blood 77:2724-2730

24. Geboes K, Ray MB, Rutgeerts P, Callea F, Desmet VJ, Vantrappen G (1982) Morphological identification of alpha-l-antitrypsin in the human small intestine. Histopathology 6:55-60

25. Perlmutter DH, Cole FS, Kilbridge P, Rossing TH, Colten HR (1985) Expression of the alpha 1-proteinase inhibitor gene in human monocytes and macrophages. Proc Natl Acad Sci USA 82:795-799

26. Salahuddin P (2010) Genetic variants of alpha1-antitrypsin. Curr Protein Pept Sci 11:101-117

27. Mahadeva R, Lomas DA (1998) Genetics and respiratory disease. 2. Alpha 1-antitrypsin deficiency, cirrhosis and emphysema. Thorax 53:501-505

28. Lara B, Martinez MT, Blanco I, Hernández-Moro C, Velasco EA, Ferrarotti I et al (2014) Severe alpha-1 antitrypsin deficiency in composite heterozygotes inheriting a new splicing mutation QOMadrid. Respir Res 15:125

29. van't Wout EF, van SA, Savage ND, Stolk J, Hiemstra PS (2012) Alpha1antitrypsin production by proinflammatory and antiinflammatory macrophages and dendritic cells. Am J Respir Cell Mol Biol 46:607-613

30. Brosseau JP, Lucier JF, Lapointe E, Durand M, Gendron D, Gervais-Bird J et al (2010) High-throughput quantification of splicing isoforms. RNA 16:442-449

31. Connell JW, Rodriguez-Martin T, Gibb GM, Kahn NM, Grierson AJ, Hanger DP et al (2005) Quantitative analysis of tau isoform transcripts in sporadic tauopathies. Brain Res Mol Brain Res 137:104-109

32. Klinck R, Bramard A, Inkel L, Dufresne-Martin G, Gervais-Bird J, Madden $R$ et al (2008) Multiple alternative splicing markers for ovarian cancer. Cancer Res 68:657-663

33. Yasen M, Mizushima H, Mogushi K, Obulhasim G, Miyaguchi K, Inoue K et al (2009) Expression of Aurora B and alternative variant forms in hepatocellular carcinoma and adjacent tissue. Cancer Sci 100:472-480

34. Shulzhenko N, Smirnova AS, Morgun A, Gerbase-DeLima M (2003) Specificity of alternative splice form detection using RT-PCR with a primer spanning the exon junction. Biotechniques 34:1244-1249 
35. Vandenbroucke II, Vandesompele J, Paepe AD, Messiaen L (2001) Quantification of splice variants using real-time PCR. Nucleic Acids Res 29:E68

36. Carlson JA, Rogers BB, Sifers RN, Hawkins HK, Finegold MJ, Woo SL (1988) Multiple tissues express alpha 1-antitrypsin in transgenic mice and man. J Clin Invest 82:26-36

37. Kelsey GD, Povey S, Bygrave AE, Lovell-Badge RH (1987) Species- and tissue-specific expression of human alpha 1-antitrypsin in transgenic mice. Genes Dev 1:161-171

38. Koopman P, Povey S, Lovell-Badge RH (1989) Widespread expression of human alpha 1-antitrypsin in transgenic mice revealed by in situ hybridization. Genes Dev 3:16-25

39. Brogna S, Wen J (2009) Nonsense-mediated mRNA decay (NMD) mechanisms. Nat Struct Mol Biol 16:107-113
40. Kervestin S, Jacobson A (2012) NMD: a multifaceted response to premature translational termination. Nat Rev Mol Cell Biol 13:700-712

41. Lee J, Novoradovskaya N, Rundquist B, Redwine J, Saltini C, Brantly M (1998) Alpha 1-antitrypsin nonsense mutation associated with a retained truncated protein and reduced mRNA. Mol Genet Metab 63:270-280

42. Boutten A, Venembre P, Seta N, Hamelin J, Aubier M, Durand G et al (1998) Oncostatin M is a potent stimulator of alpha1-antitrypsin secretion in lung epithelial cells: modulation by transforming growth factor-beta and interferon-gamma. Am J Respir Cell Mol Biol 18:511-520

43. Yuan ZA, Soprano KJ, Kueppers F (1992) Alpha-1 antitrypsin response of stimulated alveolar macrophages. J Cell Biochem 49:410-416
Submit your next manuscript to BioMed Central and take full advantage of:

- Convenient online submission

- Thorough peer review

- No space constraints or color figure charges

- Immediate publication on acceptance

- Inclusion in PubMed, CAS, Scopus and Google Scholar

- Research which is freely available for redistribution

Submit your manuscript at www.biomedcentral.com/submit 